\title{
The correlation between high sensitivity C-Reactive Protein level and the Extent of Coronary Lesion and Cardiac Systolic Function in Coronary Heart Disease
}

\author{
Miftah Suryadipradja ${ }^{*}$, Sally Aman Nasution ${ }^{f}$, Dasnan Ismail ${ }^{*}$, Yoga Iwanoff Kasjmir ${ }^{\infty}$
}

\begin{abstract}
Abstrak
Menentukan rerata kadar Protein C-Reaktif sensitivitas tinggi (hs-CRP) pada penyakit jantung koroner, hubungan antara kadar hs-CRP dengan luas lesi koroner dan fungsi sistolik jantung. Telah dilakukan penelitian observasional dengan disain potong lintang terhadap 106 pasien penyakit jantung koroner yang meliputi 90 angina pektoris stabil, 11 angina pektoris tidak stabil dan 5 infark miokard akut. Dilakukan pemeriksaan kadar kuantitatif hs-CRP, angiografi koroner untuk menentukan luas lesi koroner dan ejection fraction. Rerata kadar hs-CRP pada luas lesi koroner SVD 5,5 \pm 7,6 mg/L, DVD 6,6 \pm 21,7 mg/L dan TVD 5,5 \pm 8,0 mg/L dengan p=0,056. Tidak didapatkan hubungan bermakna antara kadar hs-CRP dengan luas lesi koroner. Fungsi sistolik jantung mempunyai korelasi negatif dengan kadar hs-CRP ( $p=0,015, r=-0,235)$. Penelitian ini menunjukkan bahwa kadar hs-CRP tidak dapat menggambarkan luas lesi koroner, kadar hs-CRP mempunyai korelasi negatif dengan fungsi sistolik jantung. (Med J Indones 2003; 12: 201-6)
\end{abstract}

\begin{abstract}
To determine the mean value of high sensitivity $C$-Reactive Protein (hs-CRP), association between plasma level of hs-CRP with extent of disease and systolic function. A cross sectional study had been conducted to 106 coronary artery disease patients $(90$ stable angina pectoris, 11 unstable angina pectoris and 5 acute myocardial infarction). Plasma quantitative level of hs-CRP with cor angiography to determine extent of disease and ejection fraction were measured. The mean of hs-CRP levels in patients with SVD were 5,5 \pm 7,6 $\mathrm{mg} / \mathrm{L}, \mathrm{DVD}$ were 6,6 $\pm 21,7 \mathrm{mg} / \mathrm{L}$ and TVD were 5,5 $\pm 8,0 \mathrm{mg} / \mathrm{L}$ and $\mathrm{p}=0,056$, respectively. There were no significant association between hs- CRP levels with extent of disease. Systolic function had negative correlation with levels of $h s-C R P(p=0,015, r=-0,235)$. This study showed that plasma level of hs-CRP cannot reflect the extent of disease, and it had negative correlation with systolic function. (Med J Indones 2003; 12: 201-6)
\end{abstract}

Keywords: high sensitivity C-Reactive Protein, extent of disease, systolic function, coronary artery diseases.

Coronary heart disease is currently still the chief cause of death in developed nations and several developing nations such as Indonesia. However, several studies demonstrate that many patients come with acute coronary syndrome, which is an emergency

\footnotetext{
* Division of Cardiology, Department of Internal Medicine, Faculty of Medicine of the University of Indonesia, Dr. Cipto Mangunkusumo National Central General Hospital, Jakarta, Indonesia

${ }^{f}$ Department of Internal Medicine, Faculty of Medicine of the University of Indonesia, Dr. Cipto Mangunkusumo National Central General Hospital, Jakarta, Indonesia

${ }^{\infty}$ Division of Rheumatology, Department of Internal Medicine, Faculty of Medicine of the University of Indonesia, Dr. Cipto Mangunkusumo National Central General Hospital, Jakarta, Indonesia
}

condition in coronary heart disease, despite having none of the known risk factors. ${ }^{1-6}$

Since it has now been found that increased C-reactive protein levels can be used to predict future cardiovascular events, the question on whether this inflammatory marker could be used to illustrate the extent and severity of atherosclerosis by establishing the extent of coronary lesion. $3,7,8$

Most previous studies that researched the correlation between C-reactive protein levels and the extent of coronary lesion have found no statistically significant correlation, but the population and methods used by the different studies vary greatly. In this study, the population covers all patients with coronary heart disease, from stable angina pectoris, unstable angina 
pectoris, and acute myocardial infarct, to hopefully illustrate coronary heart disease in general. ${ }^{9-14}$

A way to determine the consequences of such coronary lesion on cardiac systolic function, be it through an indirect mechanism, should then be contemplated. ${ }^{9}$

\section{METHODS}

This study is an observational cross-sectional study using medical records, conducted at Medistra Hospital Jakarta, from April to August 2002. The population of the study is patients with coronary heart disease, from stable angina pectoris, unstable angina pectoris, and acute myocardial infarct who are treated and hospitalized at Medistra Hospital, Jakarta. The sampling was done consecutively.

The inclusive criteria were as follows: (1) patients with coronary heart disease, including stable angina pectoris, unstable angina pectoris, and acute myocardial infarction; (2) patients with coronary heart disease who have undergone history taking, physical examination, basic laboratory assessment, cardiac enzyme assessment, high sensitivity reactive Cprotein levels at arrival, coronary angiography, and left ventriculography. The exclusion criteria were as follows: (1) acute infection in the last 2 weeks; (2) tissue injury of surgical wound within the last 2 weeks; (3) rheumatoid arthritis or other autoimmune disease; (4) liver or renal dysfunction.

In this study, the criteria for stable angina pectoris was based on the Canadian Cardiovascular Society Classification System as follows: patients with known coronary arterial disease where regular daily activity does not causes angina. Unstable angina pectoris is in line with the Braunwald classification, of specific chest pain accompanied by one of the following clinical findings: (1) Angina at rest, usually of over 20 minutes in duration within the last week; (2) new onset angina of at least class III or IV in the CCSC classification system in the last 2 months; (3) angina that has aggravated since the time of diagnosis, becoming more often, having longer duration of episodes, or a reduced threshold. While the definition of acute myocardial infarction is based on the 1979 WHO diagnosis, which is when 2 of 3 of the following symptoms are found: (1) infarct-specific chest pain: longer (over 30 minutes) and more severe, usually not alleviated by nitrates, and often requiring morphines/opioids; (2) Electrocardiographic abnormalities and specific evolution; (3) increased blood cardiac enzymes (CK, CK-MB, Troponin T/I) of at least twice the normal upper limit.

Quantitative assessment of C-reactive protein level was performed using the enzymatic immunometric assay or chemiluminescence assay, which has a high sensitivity with a 97.5 percentile level of $11 \mathrm{mg} / \mathrm{L}$ and could detect inflammatory processes down to a minimum level of $0.01 \mathrm{mg} / \mathrm{dL}$.

The extent of coronary lesion is determined based on cardiac angiography and based on a clinical scoring, stated as single vessel disease, double-vessel disease, and three-vessel disease. Quantitative cardiac angiography illustrates the extent of coronary lesion using a scoring system, as the number of blood vessels with significant stenosis (lumen diameter reduction of $70 \%$ or more). Scores range from 0 to 3 . The score according to AHA/ACC is called the extent score, measuring the involvement of coronary blood vessel segments. Evaluation of cardiac systolic function is performed as an ejection fraction calculated from the left ventriculography and stated in percentages. ${ }^{15,16}$

The data was arranged and analyzed using a statistical computer program. Univariate analysis was portrayed in the form of mean, median, standard deviation, minimum and maximum values. Bivariate analysis was performed using correlation tests between numeric variables and using the non-parametric Kruskal-Wallis test for categorical variables. Correlation tests between numeric variables were performed using the Spearman test, and the Mann Whitney test was used to establish the difference between two averages and medians.

This study did not encounter ethical problems, as samples were obtained from retrospective medical record data. The authors ensured secrecy of the medical record data in line with medical ethics.

\section{RESULTS}

The subjects that participated in the study consisted of 106 coronary heart disease patients with the following characteristics distribution: most patients were male (87 patients, $82.1 \%$ ), while only 19 were female (17.9\%); the most common clinical indication was stable angina pectoris (90 respondents, 84.9\%), followed by unstable angina pectoris in 11 patients 
(10.4\%) and acute myocardial infarct in only 5 patients $(9 \%)$; the most common extent of coronary heart lesion among the respondents in this study was single vessel disease, found in 56 subjects $(52.8 \%)$, even though the frequency was not much different with those with double-vessel disease (41 subject, $38.7 \%$ ), with only 9 subjects with three-vessel disease $(8.5 \%)$. Based on the risk factor, 76 subjects $(71.7 \%)$ were found with hypercholesterolemia. Other quite dominant risk factors included hypertension, found in 60 subjects $(56.6 \%)$, and acute myocardial infarction in 58 subjects $(54.7 \%)$. From the subjects included in this study, there were almost as many patients for whom smoking was a risk factor compared to those for whom it was not (51 and 55 patients $-48.1 \%$ and $51.9 \%$ respectively).

The mean respondent age in this study was 58 years, with the youngest being 34 years and the oldest 82 years of age. The mean high sensitivity C-reactive protein in this study was $5.9 \mathrm{mg} / \mathrm{L} \pm 14.1$, with a minimum level of $0.2 \mathrm{mg} / \mathrm{L}$ and a highest level of $132.0 \mathrm{mg} / \mathrm{L}$. Based on sex, the mean CRP level for males was higher than the mean CRP level for females, $13.2 \mathrm{mg} / \mathrm{L}$ and $4.4 \mathrm{mg} / \mathrm{L}$ respectively. The mean ejection fraction was $65.4 \%$, with a minimum EF of $29 \%$ and a maximum of $80 \%$.

Figure 1 demonstrates the distribution of mean Creactive protein level among the study sample, with several extreme values from this mean value. Table 2 demonstrates the correlation between high sensitivity $\mathrm{C}$-reactive protein and clinical indication, where the mean high sensitivity CRP level in stable angina pectoris of $5.4 \mathrm{mg} / \mathrm{L}$ is increased to $9.3 \mathrm{mg} / \mathrm{L}$ in unstable angina pectoris, but reduces to $8.2 \mathrm{mg} / \mathrm{L}$ in acute myocardial infarct. Statistically, the differences between these means were not found to be significant.

Table 1. Distribution of subject characteristics

\begin{tabular}{|c|c|c|c|c|c|}
\hline Subject Characteristic & $\mathbf{N}(\%)$ & Mean \pm SD & Median & $\begin{array}{c}\text { Minimum } \\
\text { Value }\end{array}$ & $\begin{array}{c}\text { Maximum } \\
\text { Value }\end{array}$ \\
\hline $\begin{array}{l}\text { Sex } \\
\quad \text { Male } \\
\text { Female }\end{array}$ & $\begin{array}{l}87(82.1) \\
19(17.9)\end{array}$ & & & & \\
\hline $\begin{array}{l}\text { Extent of coronary lesion } \\
\text { Single Vessel Disease } \\
\text { Double Vessel Disease } \\
\text { Three Vessels Disease }\end{array}$ & $\begin{array}{c}56(52.8) \\
41(38.7) \\
9(8.5)\end{array}$ & & & & \\
\hline $\begin{array}{l}\text { Clinical indication } \\
\text { Stable Angina Pectoris } \\
\text { Unstable Angina Pectoris } \\
\text { Acute myocardial infarction }\end{array}$ & $\begin{array}{c}90(84.9) \\
11(10.4) \\
5(4.7)\end{array}$ & & & & \\
\hline $\begin{array}{l}\text { Risk factor } \\
\text { Smoking } \\
\text { Diabetes Mellitus } \\
\text { Hypertension } \\
\text { Hypercholesterolemia } \\
\text { Hypertriglyceridemia } \\
\text { Old myocardial infarction } \\
\text { Post PTCA } \\
\text { Post CABG }\end{array}$ & $\begin{array}{l}51(48.1) \\
35(33) \\
60(56.6) \\
76(71.7) \\
21(19.8) \\
58(54.7) \\
35(33) \\
7(6.6)\end{array}$ & & & & \\
\hline Age & & $58.7 \pm 10.6$ & 57 & 34 & 82 \\
\hline Hs-CRP (mg/L) & & $5.9 \pm 14.1$ & 2.5 & 0.2 & 132.0 \\
\hline $\begin{array}{cl}\text { hs-CRP }(\mathbf{m g} / \mathbf{L}) \text { level } \\
- & \text { Male } \\
- & \text { Female }\end{array}$ & & $\begin{array}{c}13.2 \pm 29.8 \\
4.4 \pm 6.6\end{array}$ & & $\begin{array}{l}0.5 \\
0.2\end{array}$ & $\begin{array}{c}132.0 \\
36.5\end{array}$ \\
\hline Ejection Fraction (\%) & & $65.4 \pm 12.4$ & 70 & 29 & 80 \\
\hline
\end{tabular}




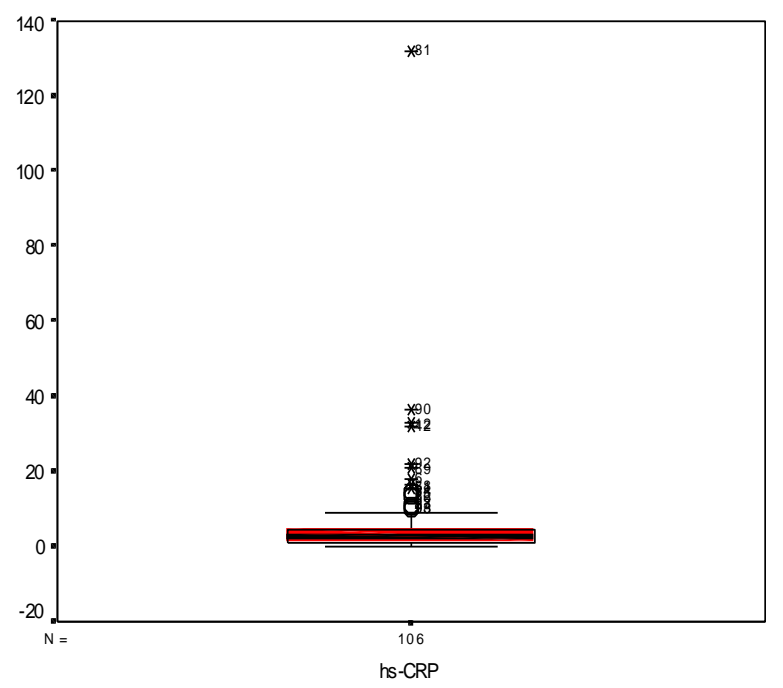

Figure 1. Distribution of subjects according to high sensitivity CRP levels

Table 2. Correlation between mean CRP and clinical indication

\begin{tabular}{cccc}
\hline & $\begin{array}{c}\text { Stable } \\
\text { Angina } \\
\text { Pectoris }\end{array}$ & $\begin{array}{c}\text { Unstable } \\
\text { Angina } \\
\text { Pectoris }\end{array}$ & $\begin{array}{c}\text { Acute } \\
\text { myocardial } \\
\text { infarction }\end{array}$ \\
\hline $\mathrm{N}$ & 90 & 11 & 5 \\
Mean CRP & 5.4 & 9.3 & 8.2 \\
\hline
\end{tabular}

In Table 3 we could see that the mean level of high sensitivity C-reactive protein for each lesion extent is as follows: $5.5 \mathrm{mg} / \mathrm{L}$ in single-vessel disease, a little higher at $6.6 \mathrm{mg} / \mathrm{L}$ in double-vessel disease, but drops to 5.45 in three-vessel disease. After statistical analysis the difference between the means was not significant. Figure 2 demonstrates a box plot of the mean C-reactive protein level for each group of coronary lesion extent, and it shows that there are a large number of extreme values above the group mean value in the group with double-vessel disease.

Table 3. Correlation between mean CRP level and the extent of coronary lesion

\begin{tabular}{cccc}
\hline & SVD & DVD & TVD \\
\hline $\mathrm{N}$ & 56 & 41 & 9 \\
Mean CRP & 5.5 & 6.6 & 5.5 \\
\hline
\end{tabular}

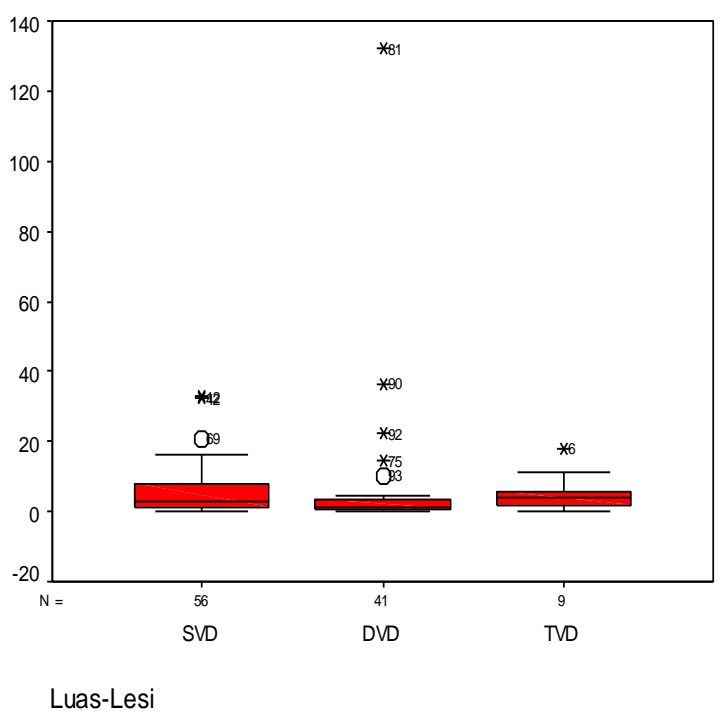

Figure 2. Correlation between mean CRP level and the extent of coronary lesion

Table 4 demonstrates the three quantitative angiography scoring results, which does not demonstrate a statistically significant correlation with mean high sensitivity C-reactive protein level. Figure 3 on the other hand, demonstrates the correlation between the mean high sensitivity C-reactive protein level and ejection fraction, which is significant with a correlation coefficient of -0.235 . This negative correlation is significant where an increased level of high sensitivity CRP means that there is a reduced ejection fraction.

Table 4. Correlation between CRP and quantitative angiography

\begin{tabular}{cccc}
\hline & Extent score & Vessel score & Stenosis score \\
\hline$p^{*}$ value & 0.552 & 0.138 & 0.975 \\
\hline
\end{tabular}

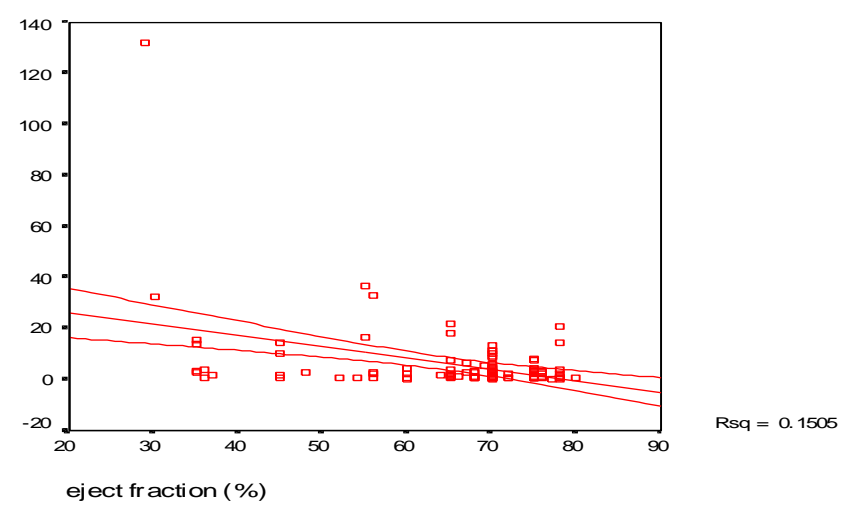

Figure 3. Correlation between CRP and ejection fraction 


\section{DISCUSSION}

One of the aims of this study is to determine the mean high sensitivity C-reactive protein level in patients with coronary heart disease, which amounts to 5.9 $\mathrm{mg} / \mathrm{L} \pm 14.1$, with a median of $2,5 \mathrm{mg} / \mathrm{L}$, and a lowest distribution of $0.2 \mathrm{mg} / \mathrm{L}$ and a highest value of 132.0 $\mathrm{mg} / \mathrm{L}$. After univariate statistical analysis using a computer program, the frequency distribution of the levels was found to be abnormal, so the first choice for analysis is by logarithmically transforming the CRP value (log natural). However, if this method is used, there will be difficulty in conducting clinical interpretation. Another analytical alternative is to use the non-parametric statistics.

Bivariate analysis between the mean C-reactive protein level and extent of coronary lesion was performed using the Kruskal Wallis test, with a result of $p=0.056$. This means that that statistically, the mean C-reactive protein level and extent of coronary lesion portrayed as single-vessel disease, doublevessel disease, and three-vessel disease does not show a significant correlation. The results is not far from previous studies, seen from the mean CRP levels for each group of lesion extent, as follows: $5.5 \mathrm{mg} / \mathrm{L}$ in single vessel disease (SVD), $6.6 \mathrm{mg} / \mathrm{L}$ in doublevessel disease (DVD), and $5.5 \mathrm{mg} / \mathrm{L}$ in triple-vessel disease (TVD). ${ }^{12}$ The lower CRP level in TVD lesions compared to DVD lesions may be due to the fact that CRP illustrates an ongoing inflammatory process, while coronary angiography demonstrates stenosis in coronary blood vessels. The lesion may be minimal (such as a less than $70 \%$ stenosis of only one blood vessel), but if the CRP level is high, references state that there is a greater risk of cardiovascular event such as acute myocardial infarct or sudden death due to cardiac causes compared to in patients without increased CRP levels. Based on the results of the analysis of mean CRP level for each clinical condition, the mean CRP level among patients with stable angina pectoris was $5.4 \mathrm{mg} / \mathrm{L}$, a higher 9.3 $\mathrm{mg} / \mathrm{L}$ in unstable angina pectoris, and then reduced again at $8.2 \mathrm{mg} / \mathrm{L}$ for acute myocardial infarct. Even though the differences in these mean averages were not significant for each clinical indication, with such mean averages, we must continue to be alert for the possibility. ${ }^{17}$

For the mean CRP levels obtained in this study, the interpretation should be in line with the method and the kit used by the laboratory to examine the Creactive protein. The kit stated $<11 \mathrm{mg} / \mathrm{L}$ as the normal level, while several studies state the normal level as $3.0 \mathrm{mg} / \mathrm{L}$.

Another problem that occurs in the interpretation of CRP results is the lack of a cutoff point, or percentile, quartile, quantile, and other terms as used in several references, for the Indonesian population. The values based on foreign references cannot be used completely, since there needs to be a large scale study in Indonesia to determine the normal range for Indonesians. In this study, the normal level used was $11 \mathrm{mg} / \mathrm{L}$, and seeing the mean C-reactive protein level of $5.9 \mathrm{mg} / \mathrm{L}$, there were not many subjects with a high range of $\mathrm{C}$-reactive protein level, but there is a tendency for it to increase to $5.4 \mathrm{mg} / \mathrm{L}$ in stable angina pectoris, $9.3 \mathrm{mg} / \mathrm{L}$ in unstable angina pectoris, and $8.2 \mathrm{mg} / \mathrm{L}$ in acute myocardial infarct. Sano et al found that among patients within 6 hours of acute myocardial infarction that underwent CK-MB, troponine $\mathrm{T}$, and $\mathrm{C}$-reactive protein, the data demonstrates no difference in CK-MB and troponine $\mathrm{T}$ levels during admission, while $\mathrm{C}$-reactive protein levels are already elevated. This demonstrates that CRP levels demonstrate previous coronary lesion prior to plaque rupture, and does not demonstrate myocardial necrosis. Plaque rupture usually occurs in areas where the fibrous cap is thin and infiltrated by macrophages.

Still in relation to the correlation between CRP and the extent of the current coronary lesion, scoring using scoring systems to determine extent, vessel, and stenosis scores was performed, with the goal of achieving more accurate results, since coronary angiography results are measured quantitatively in accordance with calculations of each scoring system. Nevertheless, no significant correlation was found between the scores and high sensitivity C-reactive protein. Such finding is in line with results from previous researchers such as Auer $J$ et al, who also studied the correlation between CRP levels and the manifestation, extent, and severity of coronary heart disease, evaluated based on coronary angiography. The researchers state that CRP level only demonstrates the presence or absence of atherosclerosis, but is not correlated with the severity or extent of the coronary heart disease itself. $^{12}$

The next aim of the study is to discover the correlation between CRP and heart systolic function, where there was a statistically significant negative correlation between cardiac systolic function demonstrated in the form of ejection fraction and CRP 
level ( $p<0.015$, correlation coefficient -0.235 ). This negative correlation is significant where increased CRP levels mean lower ejection fractions. There have not been many studies that directly correlate cardiac systolic function and C-reactive protein levels. Berton $\mathrm{G}$ et al stated that a high CRP level during acute myocardial infarction is associated with a high mortality rate and incident of cardiac failure. This study found C-reactive protein level as a very strong independent predictor of progress towards cardiac failure ( $\mathrm{p}<0.0001)$ and ejection fraction $(\mathrm{p}<0.0001)$.

As with other cross sectional studies, where all measurements and the assessment of variables is performed only once, there is of course limitations to this study. In addition, since the data used in this study is secondary data from medical records, there are of course areas of limited discourse due to data limitations.

\section{CONCLUSION}

1. The male patients in this study had a higher mean C-reactive protein level compared to the females.

2. The mean C-reactive protein level in the population of the study respondents was not too high compared to the level determined by the laboratory assessing the C-reactive protein level.

3. High sensitivity C-reactive protein levels are not correlated with the extent or severity of coronary lesion in patients with coronary heart disease.

4. High sensitivity C-reactive protein level has a statistically significant negative correlation with cardiac systolic function.

\section{Suggestion}

There needs to be a better large-scale prospective study to obtain the mean value and normal range of high sensitivity C-reactive protein levels in Indonesia.

\section{REFERENCES}

1. Santoso T. Kemajuan Kardiologi Masa Kini dan Harapan di Masa Mendatang. Dalam : Bawazier LA, Alwi I, Syam AF, Gustaviani R, Mansjoer A, eds. Prosiding Simposium
Pendekatan Holistik Penyakit Kardiovaskular, Jakarta, 2001:1-11.

2. Mayo Clinic. Coronary artery disease (serial online) September 04,2002 (cited 2003 Jan 17)[8 screen]. Available from : http:/www.mayoclinic.com/invoke.cfm.id.

3. Patel VB, Robbins MA, Topol EJ. C-reactive protein : A 'golden marker' for inflammation and coronary artery disease. Cleveland Clin J Med 2001;68(6):521-34.

4. Woodhouse S. C-reactive protein : From acute phase reactant to cardiovascular disease risk factor. Medical Laboratory Observer 2002;34(3):12-20.

5. Rifai N, Ridker PM. Inflammatory markers and coronary heart disease. Curr Opin Lipidol 2002;13:383-9.

6. Moll XG, Zouridakis E, Cole D, Kaski JC. C-reactive protein in patients with chronic stable angina : differences in baseline serum concentration between women and men. Eur Heart J 2000;21:1598-1606.

7. Ridker PM, Rifai N, Rose L, Buring JE, Cook NR. Comparison of C-reactive protein and Low Density Lipoprotein Cholesterol levels in the Prediction of First Cardiovascular Events. N Engl J Med 2002;347:1557-65.

8. Ross R. Atherosclerosis an Inflammatory Disease. N Engl J Med 1999;340:115-26.

9. Davies MJ. Coronary Disease. The Pathophysiology of Acute Coronary Syndromes. Heart 2000;83:361-6.

10. Vogel RA. Update on Inflammatory Markers. Rev Cardiovasc Med 2001;2(2):94-6.

11. Koenig W. Inflammation and Coronary Heart Disease : An Overview. Cardiology in Review 2001;9(1):31-4.

12. Auer J, Rammer M, Berent R, Weber T, Lassnig E, Eber B. Relation of C-Reactive Protein Levels to Presence, Extent, and Severity of Angiographic Coronary Artery Disease. Indian Heart J 2002;54:284-8.

13. Tataru MC, Heinrich J, Junker R, Schulte H, Von Eckardstein A, Assmann G, Koehler E. C-reactive protein and the severity of atherosclerosis in myocardial infarction patients with stable angina pectoris. Eur Heart J 2000;21:1000-8.

14. Hoffmeister A, Rothenbacher D, Bazner U, Frohlich M, Brenner H, Hombach V, Koenig W. Role of novel markers of inflammation in patients with stable coronary heart disease. Am J Cardiol 2001;87(3):262-6.

15. Gibson CM, Sandor T, Stone PH, Pasternak RC, Rosner B, Sacks FM. Quantitative Angiographic and Statistical Methods to Assess Serial Changes in Coronary Luminal Diameter and Implications for Atherosclerosis Regression Trials. Am J Cardiol 1992;69:1286-90.

16. Sullivan DR, Marwick TH, Freedman SB. A new method of scoring coronary angiograms to reflect extent of coronary atherosclerosis and improve correlation with major risk factors. Am Heart J 1990;119:1262-7.

17. Norman GR, Streiner DL. Simple Regression and Correlation. In: Norman GR, Streiner DL, eds. Biostatistics. The Bare Essentials, Ontario, 1994:106. 